\title{
PERANAN SISTEM SASI DALAM MENUNJANG PENGELOLAAN BERKELANJUTAN PADA KAWASAN KONSERVASI PERAIRAN DAERAH RAJA AMPAT
}

\section{Role of Sasi Systems In Supporting of Sustainable Management of Water Conservation Area of Raja Ampat}

\author{
*Elva Lestari dan Arif Satria \\ Departemen Sains Komunikasi dan Pengembangan Masyarakat, \\ Institut Pertanian Bogor \\ *e-mail: elvalestari2@gmail.com
}

Diterima 10 Agustus 2015 - Disetujui 25 Nopember 2015

\begin{abstract}
ABSTRAK
Kawasan Konservasi Perairan Daerah di Raja Ampat Papua Barat Indonesia pengelolaan sumber daya lautnya terdapat kearifan lokal pada masyarakat berupa Sasi. Tulisan ini bertujuan untuk mengetahui dan menganalisis pengelolaan sumber daya berbasis masyarakat, faktor eksternal dan internal yang mempengaruhi pengelolaan sumber daya, serta unsur-unsur pengelolaan sumber daya berbasis masyarakat pada Kawasan Konservasi Perairan daerah Distrik Misool Barat, Raja Ampat. Tulisan ini merupakan ringkasan hasil penelitian dengan menggunakan metode kombinasi pendekatan kuantitatif dan kualitatif. Data yang digunakan dalam penelitian ini berupa data primer dan data sekunder, dan keberlanjutan dari pengelolaan sumber daya menggunakan analisis multi-dimensional scaling (MDS). Kategori tingkat keberlanjutan sumber daya laut yang ada di Distrik Misool Barat, termasuk dalam kategori Good walaupun Kabupaten Raja Ampat secara umum merupakan kabupaten baru, namun dengan adanya Sasi yang masyarakat lakukan membuat kondisi sumber daya alam terjaga dengan baik. Dari enam kawasan konservasi di Raja Ampat salah satunya Misool yang belum lama menjadi kawasan konservasi perairan daerah, hasil penelitian yang dilakukan penulis, menunjukkan bahwa perlu adanya skala prioritas yang dilakukan oleh pemangku kebijakan, pada dua dimensi yaitu ekonomi dan teknologi. Pengelolaan sumber daya berbasis masyarakat yang dilakukan seperti di desa-desa Distrik Misool Barat berupa Sasi secara turun-temurun sampai sekarang, dalam penerapannya sudah baik, karena masyarakat yang memiliki peran penting, dari pemanfaatan, pengelolaan, pengawasan, aturan yang dibuat, sanksi, monitoring dan evaluasi, dibantu dengan ketua adat, tokoh agama, dan tokoh masyarakat selain itu dibantu oleh pihak LSM TNC. Penulis dalam penelitiannya pun menemukan hal baru yaitu mengenai Sasi "Ibu-ibu" hal ini mungkin baru pertama kali ditemukan dan didengar karena biasanya Sasi yang pernah ada dan dikelola seperti Sasi gereja, Sasi yang dikelola oleh kampung, Sasi adat. kampung, ketua adat dan tokoh agama) atau dapat langsung mengusir pelaku yang melakukan pelanggaran di wilayah Sasi dan kawasan konservasi. Sasi menjadi sangat efektif membantu dalam penerapan kawasan konservasi perairan daerah untuk keberlanjutan sumber daya alam yang ada.
\end{abstract}

Kata Kunci: konservasi perairan; keberlanjutan sumber daya laut; pengelolaan berbasis masyarakat; kearifan lokal

\section{ABSTRACT}

Regional Water Conservation Area in Raja Ampat West Papua Indonesia management of marine resources are indigenous to the community in the form Sasi. This paper aims to identify and analyze community-based resource management, external and internal factors that affect resource management, as well as elements of community-based resource management in the areas of Water Conservation Area District West Misool, Raja Ampat. This paper summarizes the results of research by using a combination of quantitative and qualitative approaches. The data used in this study are primary data and secondary data, and the sustainability of resource management using a multi-dimensional scaling (MDS). Category level of sustainability of marine resources in the District of West Misool, included in the category of Good although Raja Ampat is generally a new district, but with the Sasi that people do make the condition of natural resources are well preserved. Of the six protected areas in Raja Ampat Misool one who has recently become a water conservation area, the results of research by the author, shows that need their scale 
of priorities by stakeholders, in two dimensions, namely economic and technological. Management of community-based resource that is done as in the villages of District West Misool form Sasi hereditary until now, the application is good, because society has an important role, from the use, management, supervision, regulations made, sanctions, monitoring and evaluation. Sasi be a very effective aid in the implementation of water conservation area for the sustainability of the natural resources that exist.

\section{Keywords: water conservation, sustainability of marine resources, community-based management, local wisdom}

\section{PENDAHULUAN}

Indonesia merupakan negara kepulauan terbesar di dunia karena memiliki luas laut dan jumlah pulau yang besar. Panjang garis pantai Indonesia mencapai $104000 \quad \mathrm{~km}^{2}$ dengan luas wilayah laut yang mendominasi total luas teritorial Indonesia sebesar 7.7 juta $\mathrm{km}^{2}$. Potensi tersebut menempatkan Indonesia sebagai salah satu negara yang memiliki kekayaan keanekaragaman hayati dan non hayati yang tersebar di dunia kelautan terbesar (Data Pusat Statistik KKP, 2011). Karakteristik geografis Indonesia serta struktur dan tipologi ekosistemnya yang didominasi oleh lautan menjadikan Indonesia sebagai negara yang memiliki Mega-biodiversity terbesar di dunia, dan hal ini sekaligus merupakan justifikasi bahwa Indonesia merupakan salah satu negara bahari terbesar di dunia (Dahuri, 2003).

Konservasi sumber daya hayati laut merupakan salah satu bentuk pengelolaan ekosistem sumber daya laut dari kerusakan akibat aktivitas manusia. Pemanfaatan sumber daya alam di wilayah pesisir yang tidak terkendali dapat menyebabkan kerusakan sumber daya alam. Pemerintah pusat berwenang menetapkan kawasan konservasi yang meliputi taman nasional, taman hutan, serta taman wisata alam sebagaimana diatur dalam Undang-undang 5 Tahun 1990 (Damanik et al., 2006). Kawasan konservasi ini biasanya dilindungi oleh hukum, sehingga sering disebut pula sebagai kawasan lindung. Pengelolaan atas sumber daya alam selama ini berada dibawah kewenangan pemerintah pusat sebagaimana disebutkan dalam UUD 45 Pasal 33 Ayat 3. Dalam konteks legal makro, bahwa tanah, air, dan sumber daya alam yang terkandung di dalamnya dikelola oleh negara dan ditujukan untuk kemakmuran rakyat. Berdasarkan amanat undang-undang tersebut pemerintah menggunakan instrumen kebijakan dengan menetapkan suatu wilayah sebagai kawasan konservasi. Namun demikian penetapan kawasan konservasi yang dijadikan sebagai wilayah pemanfaatan masyarakat sering kali mengeliminasi hak-hak masyarakat untuk mengakses dan mengontrol sumber daya laut (Satria, 2009b). Sebagai contoh terjadinya pro dan kontra dalam penetapan sistim kawasan konservasi perairan daerah sebagaimana diatur dalam Peraturan Daerah Kabupaten Raja Ampat No. 27 Tahun 2008.

Masalah lain yang ditimbulkan dari praktek rezim pengelolaan terpusat adalah munculnya eksternalitas negatif di bidang perikanan, yaitu: gejala tangkap lebih (over fishing), rusaknya terumbu karang akibat aktivitas pengeboman dan penggunaan potasium sianida, rusaknya hutan mangrove dan lain sebagaimana dikutip Solihin dalam Satria 2007 bahwa pengelolaan yang sintralistik memiliki beberapa kelemahan, antara lain: (1) aturan-aturan yang dibuat kurang terinternalisasi dalam masyarakat (2) biaya transaksi yang harus dikeluarkan untuk pelaksanaan dan pengawasan sangat besar sehingga menyebabkan lemahnya penegakkan hukum.

Dengan adanya otonomi daerah atau desentralisasi dalam pengelolaan, sebenarnya awal dari pengelolaan sumber daya laut dan perikanan yang berkelanjutan, karena terdapat ruang sosial bagi masyarakat lokal untuk berpartisipasi dalam pengelolaan sumber daya yang ada, dan untuk daerah yang memiliki institusi lokal, sebagai salah satu kekuatan diterapkannya kearifan lokal dalam Undangundang No 22 Tahun 1990 (Satria, 2002a). Undang-undang No 31 Tahun 2004 tentang perikanan Pasal 2 menyebutkan bahwa, "pengelolaan perikanan dilakukan berdasarkan asas manfaat, keadilan, kemitraan pemerataan keterpaduan, keterbukaan, efisisensi dan kelestarian yang berkelanjutan". Kemudia dalam Pasal 6 Undang-undang No 31 Tahun 2004 menyebutkan "pengelolaan perikanan 
untuk kepentingan penangkapan ikan dan pembudidayaan ikan harus mempertimbangkan hukum adat dan/atau kearifan lokal serta memperhatikan peran serta masyarakat". Selanjutnya dalam Pasal 60 merupakan bagian penting dalam Undang Undang Perikanan yang mengatur hak masyarakat dalam pengelolaan Sumber Daya Perairan masyarakat memiliki hak akses maupun hak pengelolaan (Satria, 2009b).

Pengelolaan sumber daya berbasis masyarakat atau Community Based Management memberikan insentif bagi masyarakat untuk mandiri dalam wadah-wadah organisasi di tingkat lokal, pengawasan terhadap pelaksanaan lokal pun lebih efektif dan semakin kuat karena dilakukan oleh masyarakat secara lembaga (Satria, 2002a). Contoh yang paling mudah ditemukan di Indonesia adalah sistem Sasi di Maluku. Banyak fakta di negara-negara lain yang menunjukkan bahwa pengelolaan sumber daya laut yang mengutamakan nilai-nilai lokal sebagai aturan formal sangat mendukung proses pemanfaatan yang bertanggung jawab. Pemanfaatan yang bertanggung jawab mampu menjaga kelestarian sumber daya mampu dapat meningkatkan kesejahteraan masyarakat, sebagaimna dilakukan di Jepang dengan menggunakan fishery right. Sistim fishery right tersebut diangkat dari hak-hak ulayat (soyu) yang dulu pernah berkembang di Jepang dan telah mengakar dalam diri masyarakat nelayan Jepang (Satria et al., 2002a). Keuntungan sistem pengelolaan sumber daya berbasis masyarakat sudah banyak dikenal dalam kegiatan irigasi, hutan masyarakat dan pertanian. Mudahnya pengawasan yang dilakukan secara langsung oleh masyarakat terhadap lingkungan sumber dayanya, sehingga dapat menjaga kelestarian sumber daya (Satria, 2007). Selain itu dengan adanya pengelolaan sumber daya berbasis masyarakat, membuka ruang bagi masyarakat untuk berpartisipasi dan menjaga keberlanjutan dari sumber daya laut.

Upaya pengelolaan berbasis masyarakat di sektor perikanan dan kelautan umumnya masih dalam tahap pengembangan. Hal ini barangkali disebabkan oleh rumitnya sistem sumber daya pesisir dan laut serta struktur sosial budaya masyarakat nelayan/pesisir (Bengen 2001). Namun terdapat kelebihan dari pengelolaan berbasis masyarakat dalam pengelolaan perikanan contohnya di Wilayah Lombok Utara adalah salah satunya dapat diterima oleh semua lapisan masyarakat, karena sesuai dengan aspirasi dan keinginan masyarakat sendiri serta sesuai dengan budaya lokal. Selain di Wilayah Lombok dan sistem Sasi di Maluku, pengelolaan berbasis masyarakat dalam pengelolaan perikanan, ada pula sasi yang ada di Kabupaten Raja Ampat, salah satunya Distrik Misool Barat salah satu dari enam Kawasan Konservasi Perairan Daerah di Raja Ampat.

Sebagai kawasan ke-V di TPPKD Raja Ampat, kawasan konservasi Tenggara Misool, memiliki tiga kecamatan (distrik) di dalam kawasan konservasi ini, termasuk di dalamnya Misool Barat. Misool Barat memiliki 5 (lima) desa dalam kawasan konservasi yaitu: Biga, Gamta, Lilinta, Magey dan Kapatcol. Pusat pemerintahan Distrik Misool Barat terletak di Kampung Lilinta. Penduduk di Distrik Misool Barat pada tahun 2012 tercatat sejumlah 1425 jiwa. Desa Lilinta memiliki jumlah penduduk paling banyak di Distrik Misool Barat,kepadatan penduduk terkecil adalah di Desa Magei dan Desa Kapatcol. Menurut jenis kelamin penduduk laki-laki sebanyak 931 jiwa dan perempuan 739 jiwa. Penduduk Distrik Misool Barat sebagian besar beragama Islam. Mata pencaharian penduduk mayoritas sebagai petani dan nelayan. Hampir semua warga masyarakat di Misool Barat memiliki alat transportasi katinting bermotor. Alat-alat tangkap yang digunakan oleh nelayan di Distrik Misool Barat sebagian besar adalah pancing dasar, kemudian jaring dan ada beberapa orang yang juga masih menggunakan bubu. Masyarakat Misool Barat hanya mengenal dua musim dalam kegiatan menangkap ikan yaitu musim angin selatan dan musim angin barat, musim angin selatan biasanya terjadi pada bulan Juni-Oktober. Pada saat bulan JuniOktober terdapat Sasi musiman, kemudian pada saat angin musim selatan dilakukan tutup Sasi, dan Bulan November-April nelayan kemudian kembali mencari ikan di laut, kemudian menggunakan kesempatan untuk buka Sasi.

Tulisan ini mencoba menilai berkelanjutan dari setiap dimensi dengan menggunakan metode multi variabel yang disebut multidimensional scaling (MDS). Metode ini digunakan untuk menilai secara cepat status keberlanjutan pengelolaan sumber daya alama. 
Hal tersebut dapat diindikasikan bahwa masyarakatadatmenjaga sumber daya laut, untuk keberlanjutan kehidupan mereka, karena secara tidak langsung kehidupan mereka tergantung dengan laut. Salah satu cara yang dikembangkan untuk melihat keberlanjutan dalam pengelolaan sumber daya laut berbasis masyarakat adalah dengan. Metode tersebut yang digunakan oleh penulis untuk menilai keberlanjutan di Raja Ampat, tepatnya di daerah Distrik Misool Barat, selain itu perlu ada kajian dan beberapa hal yang perlu dipertimbangkan karena masih sedikit penelitian mengenai pengelolaan sumber daya laut berbasis masyarakat secara khusus pada kawasan konservasi di beberapa wilayah Distrik Raja Ampat. Tulisan ini merupakan hasil penelitian ini dilakukan di Distrik Misool Barat, Kabupaten Raja Ampat, Papua Barat. Permasalahan yang diangkat dalam tulian ini adalah: Sejauh mana tingkat keberlanjutan pengelolaan sumber daya berbasis masyarakat (PSBM) di Distrik Misool Barat, Kabupaten Raja Ampat, Papua Barat. Hal tersebut dikarenakan sebagian besar masyarakat yang tinggal di wilayah Raja Ampat adalah nelayan, dan juga dikarenakan adanya kearifan lokal masyarakat di daerah tersebut berupa Sasi.

\section{METODOLOGI}

Penelitian ini menggunakan pendekatan kualitatif dengan kerangka pikir sebagaimana disajikan dalam Gambar 1.
Metode kualitatif dilakukan melalui observasi lapang secara langsung kehidupan sosial masyarakat dan wawancara mendalam dengan menggunakan panduan pertanyaan. Lokasi penelitian dilakukan di Distrik Misool Barat, Kabupaten Raja Ampat, Papua Barat. Pemilihan lokasi tersebut dilakukan secara sengaja (purposive) dengan beberapa alasan, yakni: (1) Disitrik Misool, Kabupaten Raja Ampat, Papua Barat merupakan kawasan konservasi perairan daerah yang ditetapkan menurut Keputusan Menteri Kelautan dan Perikanan Nomor 64/Men/2009 Tgl 3 September 2009. (2) Adanya pengelolaan sumber daya masyarakat berbasiskan kearifan lokal. Jumlah informan dalam penelitian ini tidak dibatasi, untuk memperkaya informasi mengenai pengelolaan sumber daya berbasis masyarakat berupa Sasi dan kawasan konservasi perairan daerah di Distrik Misool Barat. Penulusuran dilakukan pada pihak-pihak terkait dengan menggunakan teknik bola salju (snowball sampling) yang memungkinkan perolehan data dari satu informan ke informan lainnya. Pencarian informan ini berhenti, saat tambahan informan tidak lagi menghasilkan pengetahuan baru sudah berada di titik jenuh, terdapat informan kunci dalam pencarian informasi. Informan kunci yang pertama kali diwawancarai adalah pihak kepala Distrik Misool Barat. Informan yang terdapat pada penelitian ini yaitu kepala Distrik Misool Barat, kepala BAMUSKAN Desa Lilinta,

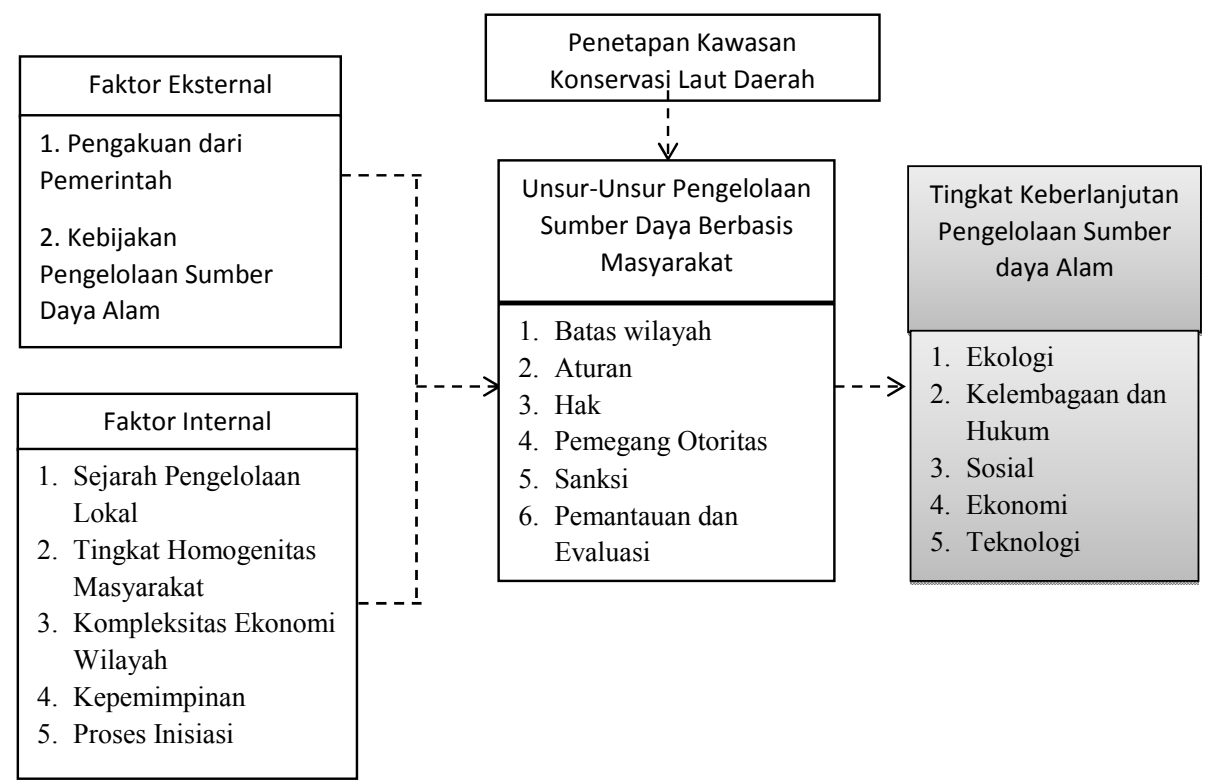

Gambar 1 Kerangka Pikir Penelitian 
ketua adat Desa Lilinta, kepala kampung Desa Kapatcol, ketua adat Desa Kapatcol, LSM TNC, 4 orang Nelayan, Ketua Sasi "ibu-ibu" dan 7 orang anggota Sasi "ibu-ibu".

Selain metode kualitatif penelitian ini juga menggunakan metode survey dengan instrumen kuesioner. Responden yang dipilih adalah warga masyarakat yang memiliki pekerjaan sebagai nelayan atau warga masyarakat lain yang mengerti permasalahan kegiatan melaut. Jumlah responden sebanyak 40 orang. Penentuan responden dalam penelitian dilakukan dengan menggunakan simple random sampling, sebuah sampel yang diambil sedemikian rupa sehingga tiap unit penelitian atau satuan elementer dari populasi mempunyai kesempatan yang sama untuk dipilih sebagai sampel (Singarimbun, 1989). Teknik pengolahan data menggunakan Microsoft Excell 2010, dalam mengukur tingkat keberlanjutan KKPD adalah dengan menggunakan analisis statistik multivariate berupa analisis Multidimensional Scaling (MDS) dengan menggunakan software SPSS Statistics20 for windows. Pendekatan multi dimensional scalling (MDS) merupakan metode analisis penelitian dengan menggunakan Leverage analysis, pendekatan ini merupakan pendekatan yang dimodifikasi dari program Rapfish.

\section{HASIL DAN PEMBAHASAN}

\section{Pengelolaan Sumber Daya Berbasis Masyarakat}

Istilah moderen Sasi dikenal sebagai konservasi tradisional, dengan model pengelolaan berbasis masyarakat telah berlangsung secara turun-temurun. Pada awalnya praktek Sasi terdapat Maluku, kemudian menyebar ke wilayah kawasan Papua, termasuk di wilayah Distrik Misool Barat, Kabupaten Raja Ampat Papua Barat, dan salah satunya di wilayah Lilinta dan Sasi "ibu-ibu". Menurut Ruddle (1999) sebagaimana dikutip Satria (2009b), menyebutkan bahwa unsurunsur pengelolaan sumber daya perikanan berbasis masyarakat antara lain: batas wilayah, aturan, hak, pemegang otoritas, sanksi, dan monitoring serta evaluasi. Pada pengelolaan sumber daya berbasis masyarakat di kawasan Distrik Misool Barat berupa Sasi laut, contoh pada Sasi yang dilakukan di Desa Lilinta dan Desa Kapatcol adalah praktek Sasi yang khusus untuk melarang penangkapan biota laut yaitu: lola, teripang, lobster dan juga ikan (khusus di Kapatcol), sedangkan jenis biota lainnya tidak di Sasi.

\section{Batas Wilayah}

Batasan wilayah daerah yang diatur dalam Sasi di Distrik Misool Barat adalah seluruh batas wilayah laut di area desa tersebut, dengan menggunakan tanda batas tanda alam (natural sign) seperti kampung dengan kampung dan pulau dengan pulau, untuk memberitahukan bahwa wilayah tersebut telah di Sasi atau dengan menggunakan pelampung, kayu-kayu, dan papan yang bertulisakan Sasi. Area Sasi termasuk ke dalam kawasan konservasi yang dimanfaatkan oleh masyarakat, wilayah kawasan konservasi sendiri meliputi beberapa pulau saja yang dikavling untuk wilayah konservasi, tetapi ketika di dalam pembukaan Sasi maka wilayah-wilayah yang di kavling sebagai wilayah

Tabel 1 Perbedaan Batas Wilayah KKPD dan Sasi di Misool Barat.

\begin{tabular}{|c|c|c|}
\hline \multicolumn{3}{|c|}{ Batas Wilayah } \\
\hline Perbedaan & Kawasan Konservasi Perairan Daerah & Sasi \\
\hline $\begin{array}{l}\text { Kejelasan } \\
\text { Wilayah }\end{array}$ & $\begin{array}{l}\text { Batas wilayah jelas, dengan pembagian } \\
\text { zona-zona dalam pengelolaan dan } \\
\text { pemanfaatannya. }\end{array}$ & $\begin{array}{l}\text { Batas wilayah tidak terlalu jelas, namun masyarakat/ } \\
\text { nelayan mengetahui batasan wilayah yang di Sasi }\end{array}$ \\
\hline Formalitas & $\begin{array}{l}\text { Pembentukan batas wilayah bersifat } \\
\text { formal dan diatur dalam peraturan tertulis }\end{array}$ & $\begin{array}{l}\text { Pembentukan batas wilayah bersifat informal, } \\
\text { yaitu batas wilayah buka dan tutup Sasi, dengan } \\
\text { ketentuan disepakati bersama oleh masyarakat di } \\
\text { desa dan petuanan (ketua adat) }\end{array}$ \\
\hline Tanda & $\begin{array}{l}\text { Batas wilayah menggunakan tanda alam } \\
\text { yaitu antara kampung dengan kampung, } \\
\text { pulau dengan pulau dan semenanjung } \\
\text { dengan semenanjung }\end{array}$ & $\begin{array}{l}\text { Batas wilayah menggunakan tanda alam yaitu batas } \\
\text { antara kampung atau antar pulau, wilayah yang di } \\
\text { Sasi, selain itu menggunakan kayu dan papan yang } \\
\text { bertulisakan wilayah Sasi }\end{array}$ \\
\hline
\end{tabular}


Sasi kemudian dibuka agar masyarakat dapat memanfaatkan dan mengelola hasil dari sumber daya laut. Sebelum ada kawasan konservasi, masyarakat menetapkan batas-batas wilayah Sasi secara imaginer, yaitu berupa pulau-pulau di sekitar kampung. Pada kawasan konservasi terdapat zona-zona di kawasan konservasi yang diatur dalam setiap kegiatan pemanfaatan sumber daya. Di Misool Barat terdapat enam pembagian kawasan zona yang ditetapkan yaitu: zona inti, zona pemanfaatan terbatas (Sub zona ketahanan pangan dan parwisata juga sub zona perikanan berkelanjutan dan budidaya), zona pemanfaatan lainnya (Sub zona pemanfaatan tradisonal masyarakat, sub zona Sasi dan sub zona pemanfaatan umum). Dari hasil pengamatan dan wawancara masyarakat hanya mengetahui dua zona secara garis besar yaitu zona inti dan zona pemanfaatan tradisional berupa zona Sasi.

Batas wilayah yang telah diatur oleh pemerintah memang sudah baik, dengan zona-zona yang diatur dengan jelas pada kawasan konservasi perairan daerah di Distrik Misool Barat, namun berdasarkan dari hasil wawancara menunjukan bahwa aturan dalam kwasan konservasi tidak ditaati oleh masyarakat oleh masyarakat, tetapi masih tetap mengambil ikan disekitar kawasan dan bahkan sampai ke dalam konservasi karena tuntutan kebutuhan hidup. Hal ini berbeda dengan batas wilayah Sasi yang ditetapkan oleh ketua adat bersama masyarakat, meskipun pembentukan wilayah Sasi belum jelas dan bersifat informal. Masyarakat lebih mematuhi aturan Sasi (legitimasi adat).

\section{Sistim Aturan}

Tidak ada aturan tertulis dan baku dalam penerapan Sasi di Distrik Misool Barat. Namun masyarakat sudah mengetahui dan memahami mengenai aturan adat tersebut saat buka Sasi ataupun saat tutup Sasi. Aturan Sasi yang diterapkan yakni, pada saat tutup Sasi masyarakat hanya boleh melintas di area yang di Sasi, tidak diperbolehkan mengambil lola, lobster, teripang, dan ikan yang juga di Sasi di wilayah tersebut. Saat dimulai penutupan Sasi, maka saat itulah aturan Sasi diberlakukan, aturan berakhir ketika telah diumumkan bahwa sudah saatnya buka Sasi. Mekanisme dalam menutup dan membuka Sasi hampir sama di seluruh desa di Distrik Misool Barat penerapannya.

Apabila ada warga yang melanggar akan diberikan sanksi. Pengambilan keputusan yang melanggar aturan, tokoh adat, tokoh agama dan pemerintah yang berhak menentukan hukuman yang didapat oleh pihak yang melanggar.

\section{Tabel 2 Mekanisme Buka Sasi dan Tutup Sasi.}

\begin{tabular}{ll}
\hline \multirow{2}{*}{ No } & \multicolumn{1}{c}{ Tutup Sasi } \\
\cline { 2 - 3 } & Terdapat pengumuman yang diberikan oleh kepala \\
& adat ke masyarakat, bahwa akan segera dilakukan \\
& tutup Sasi. Masyarakat di desa tersebut dan diluar \\
& diharapkan mengetahui dan mematuhi segala \\
& peraturan yang ada. mematuhi aturan yang sudah \\
& ditetapkan.
\end{tabular}

2. Diadakan pertemuan terlebih dahulu, yakni musyawarah antar kepala Rukun Tetangga, tokoh agama, tokoh masyarakat, dan beberapa perwakilan masyarakat lainnya untuk menetapkan kesepakatan bahwa sudah waktunya tutup Sasi.

3 Pada saat tutup Sasi, diadakan upacara adat dan upacara agama, ada pula yang hanya upacara adat saja, contoh di Lilinta. Upacara yang dilakukan berupa doa dari pendeta gereja dan ketua adat. Ada peresmian bahwa tutup Sasi sudah dilakukan. Periode tutup Sasi berbeda-beda tergantung dari kesepakatan yang ditetapkan, Sasi Musiman lamanya 6 (enam) bulan, Sasi Kampung dan Sasi Gereja lama Sasi yang diterapkan dapat dilakukan 1 atau bahkan 2 tahun sekali.

\section{ekanisme}

Membuka Sasi dilakukan sama seperti halnya tutup Sasi, yaitu dengan diadakannya pengumuman bahwa akan segera dilakukan buka Sasi. Diadakan pertemuan antara tiga tungku,kepala Rukun Tetangga dan perwakilan dari masyarakat. Memberitahukan desa-desa di sekitarnya (dalam satu Distrik) untuk diundang saat upacara buka Sasi.

Musyawarah dilakukan terlebih dahulu untuk kesepakatan buka Sasi, selanjutnya kesepakatan yang sudah disepakati diumumkan dari kepala adat dan disebarkan dari mulut ke mulut.

Acara pembukaan Sasi sama halnya seperti saat tutup Sasi. Hasil dari Sasi tidak semuanya dapat diambil, ada monitoring dari pihak LSM TNC terkait ukuran yang dapat diambil. Hasil dari biota laut yang terkumpul (teripang, lola, lobster, batu laga) dan dimonitoring kemudian ada pembagian hasilnya yaitu untuk gereja dan masyarakat. Buka Sasi biasanya berlangsung 3 (tiga) sampai 7 (tujuh) hari, tergantung kesepakatan. 


\section{Sistim Hak}

Menurut Ostrom dan Schlager (1990) dikutip Satria (2009), hak kepemilikan dibagi menjadi lima macam meliputi: hak akses, hak pemanfaatan hak pengelolaan, hak eksklusi dan hak pengalihan. Terdapat hak ulayat di Misool Barat dengan petuanan yang menguasai beberapa luas wilayah perairan salah satunya di Misool Barat yaitu di daerah Lilinta, secara global hak ulayat dimiiki marga tertentu, tetapi dalam pengelolaannya dikelola untuk keseluruhan masyarakat yang tinggal dan hidup di daerah,Masyarakat di wilayah Distrik Misool Barat, memiliki hak dalam pengambilan/ penangkapan ikan yaitu dapat melintasi kawasan yang di Sasi pada saat tutup Sasi, namun dalam memanfaatkan sumber daya laut hanya bisa saat buka Sasi, selain itu hak lainnya masyarakat turut serta untuk mengambil keputusan dan mengawasi pelaksanaan Sasi. Tidak ada hak eksklusif dalam pengelolaan Sasi disana. Menurut Ostrom dan Schlager (1990) dikutip Satria (2009), status atau posisi individu dalam suatu masyarakat berkaitan dengan hak kepemilikan yang dimiliki, di Distrik Misool Barat termasuk pada Claimant karena nelayan memiliki hak akses, hak pemanfaatan, dan hak pengelolaan sumber daya laut yang ada disana.

\section{Sistim Sanksi}

Sanksi dalam Sasi yang diberlakukan terkait pengelolaan sumber daya berbasis masyarakat adalah jika ada warga masyarakat yang melanggar aturan tersebut maka ada hukuman. Mekanisme pemberian sanksi terhadap para pelanggar tergantung dengan ketua adat, hukuman dapat berupa kegiatan fisik, denda, atau alat tangkapnya diambil. Kegiatan fisik misalnya, untuk pihak yang melanggar, dia harus mengangkat batu untuk masjid atau berjalan jongkok dan berkeliling di desa. Hal ini tidak hanya berlaku untuk Sasi, jika ada nelayan dari luar mengambil ikan atau biota lautnya di kawasan konservasi maka akan diberikan sanksi tersebut karena belum ada peraturan tertulis yang dibuat. Beberapa sanksi yang diberlakukan jika didapati ada yang melanggar saat diadakannya tutup Sasi.

\section{Pemegang otoritas}

Ketua adat di distrik Misool Barat sangat berperan penting untuk mengadakan dan mengatur Sasi tersebut, selain itu otoritas juga melekat pada pemerintahan desa dan tokoh agama yaitu pendeta gereja. Setiap keputusan yang ada dalam pengelolaan dan pemanfaatan sumber daya laut dimusyawarahkan terlebih dahulu bersama-sama dengan masyarakat, seperti untuk buka dan tutup Sasi. Ketua adat di Desa Lilinta ditempatkan sebagai kekuasaan tertinggi untuk mengatur pemanfaatan sumber daya laut dan menjaga sumber daya laut untuk sekarang dan masa depan yang akan datang, karena kehidupan mereka bergantung kepada laut.

\section{Pengawasan dan Evaluasi}

Monitoring dan evaluasi Sasi yang ada di Misool Barat dilakukan oleh masyarakat dibantu oleh pihak LSM TNC, yaitu melalui keterlibatan kelompok pengawas yang berkeliling pulau dengan membawa lembaran catatan jika ada yang melanggar sekaligus memonitoring kawasan konservasi yang ada di daerah tersebut. Mekanisme dalam pengawasan Sasi jika ada masyarakat mengetahui ada yang melanggar maka harus memberitahukan kepada tiga tungku (kepala kampung, ketua adat dan tokoh agama) atau dapat langsung mengusir pelaku yang melakukan pelanggaran. Teknik dalam pengawasan yang dilakukan berupa patroli dan masyarakat yang memancing di dekat kawasan Sasi maupun kawasan konservasi, jika ada nelayan dari luar yang memancing di kawasan tersebut, maka masyarakat melaporkan kepada kepala kampung atau ketua adat.

\section{Sasi "lbu-ibu"}

Selain Sasikampung, Sasigereja, terdapat Sasi musiman yaitu pada saat angin musim selatan yang digunakan untuk tutup Sasi dan angin musim barat digunakan untuk buka Sasi. Distrik Misool Barat di Desa Kaptcol, terdapat Sasi yang khusus di kelola oleh ibu-ibu di luar Sasi kampung dan gereja. Ibu-ibu di kampung Kapatcol melihat hasil dari Sasi Kampung sangatlah baik dan hasilnya memuaskan, semenjak saat itu ibu-ibu terutama ketua dari Sasi "ibu-ibu" yaitu Ibu Bedsinah Hai berinisiatif untuk membuat Sasi khusus untuk Ibu-ibu. Pada tahun yang sama itu pula, ibu-ibu kemudian membuat Sasi yang letaknya tidak begitu jauh tempatnya, di tanjung di depan kampung, namun pada awal buka Sasi, tidak ada hasil yang didapat atau bisa dikatakan bahwa Sasi tersebut gagal 
karena tidak ada hasil dari Sasi yang dilakukan. Unsur-unsur pengelolaan berbasis masyarakat berupa sasi "ibu-ibu", tidak berbeda jauh dengan unsur-unsur PSBM (Pengelolaan Sumber daya alam Berbasis Masyrakat) "Sasi" secara umum di Dsitrik Misool Barat.

\section{Faktor Eksternal}

\section{a. Pengakuan dari pemerintah}

Sasi merupakan kearifan lokal yang sudah secara turun-temurun dilakukan oleh masyarakat di Distrik Misool Barat, telah diakui oleh masyarakat yang dibuktikan dengan membuat kawasan konservasi perairan daerah yang melibatkan unsur pemerintah, masyarakat dan LSM dalam membuat kebijakan, yang memperhatikan praktek Sasi yang sudah lama berlangsung di Distrik Misool Barat. Peran Sasi dinilai penting dalam pembuatan aturan-aturan kawasan konservasi perairan daerah

\section{b. Kebijakan pengelolaan sumber daya}

Kebijakan pengelolaan sumber daya laut pada dasarnya memiliki tujuan yaitu meningkatkan kesejahteraan seluruh masyarakat (social well-being) di daerahnya secara berkelanjutan. Kebijakan pemerintah yang melibatkan peran Sasi memberikan kesempatan bagi seluruh masyarakat untuk dapat mengelola dan memanfaatkan sumber daya laut, dan didalamnya terdapat kesepakatan-kesepakatan bersama yang dibuat oleh masyarakat, ketua adat, tokoh masyarakat dan kepala kampung dengan ketua adat yang memiliki kedudukan tertinggi.

\section{Faktor Internal}

\section{a. Tingkat Homogenitas Masyarakat}

Di Distrik Misool Barat merupakan sekumpulan masyarakat yang hidup bersama-sama mendiami wilayah pesisir (Satria 2004) yaitu desa-desa yang ada berada di sana, dari segi mata pencaharian utama lebih banyak sebagai nelayan karena demografi mereka yang mendukung mereka bekerja sebagai nelayan, sedikit dari mereka yang bekerja sebagai petani yaitu di daerah Biga, Gamta dan Magey. Masyarakat yang tinggal di desa, biasanya masih memiliki hubungan saudara dan memiliki garis keturunan yang sama atau satu suku, dua suku yang terkenal di Distrik Misool yaitu Matbat dan Matlo

\section{b. Sejarah pengelolaan lokal}

Dalam segi pengelolaan sumber daya, pengelolaan sumber daya didasarkan atas pengetahuan lokal (Satria 2009b), tunduk dan selaras dengan alam (Kluckhon dalam Satria 2002b), yakni masyarakat di Misool Barat secara terus menerus melakukan kegiatan Sasi yang telah mereka sadari bahwa kearifan lokal tersebut akan menjadi hal yang berguna, sebagai tabungan untuk anak dan cucuk mereka di masa yang akan datang. Sasi yang dilakukan tidak hanya Sasi

\section{c. Kompleksitas ekonomi wilayah}

Wilayah di Distrik Misool Barat, sebagian besarbekerjauntukmenghidupi kebutuhannya menjadi seorang nelayan, namun di beberapa desa di Misool Barat, menghidupi kehidupannya dengan bercocok tanam dengan komoditas unggulan adalah sagu, masih ada sistem barter dalam memenuhi kebutuhan dengan cara masyarakat di desa Biga datang ke Lilinta untuk menjual sagu, masyarakat dari Lilinta membayar sagu tersebut dengan ikan. Membahas ekonomi di wilayah Distrik Misool Barat, seperti yamg telah dipaparkan bahwa masyarakat tunduk dan selaras dengan alam.

\section{Kepemimpinan dan proses inisiasi}

Kepemimpinan dalam pengelolaan sumber daya di Distrik Misool Barat, ketua adat yang berperan penting dalam mengatur pengelolaan tersebut, yaitu saat buka dan tutup Sasi, namun peran tokoh agama seperti pendeta dan kepala kampung juga memiliki peran yang penting dalam segi pengelolaannya.

Proses inisiasi dalam pengelolaan sumber daya penulis mengambil contoh pada Sasi ibu-ibu, karena melihat hasil yang memuaskan dan bagus pada saat buka Sasi kampung.

\section{Tingkat Keberlanjutan Sumber Daya Laut di Kawasan Konservasi Perairan Daerah.}

Dari kelima dimensi keberlanjutan yaitu: dimensi sosial, hukum dan kelembagaan, sosial, 


\section{Diagram Layang-layang Dimensi Keberlanjutan}

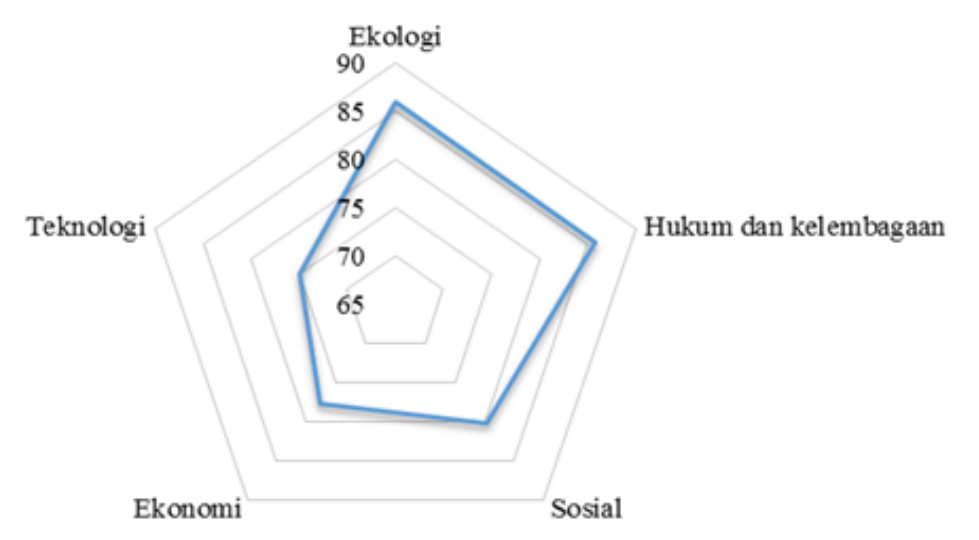

Gambar 2. Diagram Layang-layang Dimensi Keberlanjutan

ekonomi, dan teknologi, secara keseluruhan (Goodness of fit) termasuk pada kategori "Good", namun terdapat dua dimensi yang perlu mendapatkan perhatian utama dibandingkan dimensi yang lain, dimensi tersebut yaitu dimensi ekonomi dan teknologi. Hal tersebutkarena kedua dimensi memiliki nilai yang rendah, walaupun dilihat pada nilai s-strees, dimensi ekonomi dikategorikan "Perfect", dan dimensi teknologi dikategorikan "Excelent", untuk dimensi teknologi masyarakat terutama responden banyak yang berkata dari segi teknologi masih sangat kurang diperhatikan, dalam pembangunan sarana dan prasarana untuk pengelolaan sumber daya di kawasan konservasi perairan daerah. Dimensi ekonomi sendiri perlu perhatian lebih oleh pemerintah karena masyarakat pekerjaan utamanya menangkap ikan, namun dalam segi pemasukan nelayan hanya bergantung pada hasil melaut, yang menjadikan masyarakat mengalami kesulitan dalam memenuhi kebutuhan saat tidak melaut terutama pada saat angin musim selatan, bantuan berupa katinting yang diberikan pun masih belum tepat sasaran, koperasi nelayan pun belum ada di daerah tersebut yang sebenarnya dapat membantu pengelolaan keuangan nelayan.

\section{KESIMPULAN DAN IMPLIKASI KEBIJAKAN}

\section{Kesimpulan}

Pengelolaan kawasan konservasi perairan daerah, berjalan baik karena mengadopsi sistem Sasi. Sasi merupakan kearifan lokal yang sudah secara turun-temurun dilakukan oleh masyarakat di Distrik Misool Barat. Kegiatan Sasi yang dilakukan sejak lama untuk menjaga sumber daya alam yang ada agar terjadi berkelanjutan. Sasi telah diakui oleh pemerintah. Dalam membuat kawasan konservasi perairan daerah, pemerintah, masyarakat dan LSM membuat kebijakan yang memperhatikan sistim Sasi. Pemerintah pusat memiliki kebijakan dalam pengelolaan sumber daya dengan membuat aturan-aturan dan membuat suatu kawasan dengan zona-zona di dalamnya.

\section{Implikasi Kebijakan}

Tingkat keberlanjutan sumber daya laut di Distrik Misool Barat, termasuk kategori Good, walaupun Kabupaten Raja Ampat secara umum merupakan kabupaten baru, namun dengan adanya Sasi yang masyarakat lakukan membuat kondisi sumber daya alam terjaga dengan baik. Pada dimensi ekonomi atribut yang sangat perlu di prioritaskan demi keberlanjutan sumber daya alam adalah pemberdayaan nelayan dalam bidang ekonomi/koperasi dan pemasukan lain selain melaut. Masyarakat beranggapan belum adanya perhatian khusus dari pemerintah untuk mereka terutama dari segi pemenuhan ekonomi, walaupun sumber daya alam laut di Distrik Misoo/Barat sangat baik dan melimpah. Dimensi teknologi atribut yang perlu diprioritaskan untuk perbaikan menggunakan alat tradisional yang masih masyarakat menggunakan bom atau sianida.

Keberadaan kelompok nelayan khusus perlu diperhatikan untuk mengawasi dan 
menjaga kawasan konservasi perairan daerah, dan termasuk kawasan Sasi. Hal ini dilakukan untuk mengurangi kegiatan negatif yang merusak sumber daya. Selain itu dengan adanya pengalokasian dana dari pemerintah membantu masyarakat di sekitar kawasan konservasi perairan daerah bertujuan agar kegiatan pengawasan konservasi sendiri/ patroli pengawasan oleh kelompok masyarakat pengawasn berjalan baik.

\section{DAFTAR PUSTAKA}

Dahuri, R. 2003. Paradigma Baru Pembangunan Indonesia Berbasis Kelautan, dalam Orasi IImiah : Guru Besar Tetap Bidang Pengelolaan Sumber Daya Pesisir dan Lautan Fakultas Perikanan dan IImu Kelautan InstitutPertanian Bogor. [Internet]. Bogor [ID]. [diunduh 10 Januari 2014]. Dapat diunduh dari http://repository.ipb. ac.id/bitstream/handle/123456789/43952/ Isi.pdf?sequence=2.

Damanik R., A, Satria. dan B. Prasetiamartati. 2006. Menuju konservasi laut yang pro rakyat dan pro lingkungan. Wahana Lingkungan Hidup Indonesia (WALHI). Jakarta.

[KKP] Kementerian Kelautan dan Perikanan. 2011. Data Pokok Kelautan dan Perikanan Periode s.d Oktober 2011. [Internet]. Indonesia [ID]. [diunduh pada 6 Januari 2014]. Dapat diunduh pada http:// perpustakaan.bappenas.go.id/lontar/ opac/themes/bappenas4/templateDetail. jsp?id=142466\&lokasi=lokal.
Satria A., A, Umbari., A, Fauzi., A, Purbayanto., E, Sutarto., I, Muchsin., I, Muflikhati., M, Karim., S, Saad., W, Oktariza. dan Z, Imran. 2002. Menuju desentralisasi kelautan. Pusat kajian Agraria IPB, Partnership in Indonesia dengan PT Pustaka Cidesindo. Jakarta.

Satria, A. 2002. Sosiologi Masyarakat Pesisir. PT Pustaka Cidesindo. Jakarta.

Satria, A. dan Y, Matsuda. 2004. Decentralization of fisheries management in Indonesia. Dalam: Journal of Marine [Internet]. [dikutip 8 Januari 2014]; 28(2004): 437-450.doi:http://ledhyane.lecture.ub.ac. id/files/2013/02/09.pdf.

Satria, A. 2007. Sawen Instituion, local knowledge and myth in fiheries management in Nort Lombok, Indonesia.Fishers' knowledge in fisheries science and management. UNESCO. Paris.

Supriharyono. 2007. Konservasi Ekosistem Sumber daya hayati di WilayahPesisir dan Laut Tropis. Pustaka pelajar. Yogyakarta. 